\title{
Improving the Ability of English Teachers in Implementing STAD Type Cooperative Learning Model Through Clinical Supervision at SMP Negeri Kecamatan Sunggal
}

\author{
Suzatmiko Wijaya \\ Educational Administration \\ Universitas Negeri Medan \\ Medan, Indonesia \\ Suzatmikowijaya8@gmail.com
}

\author{
Sukarman Purba \\ Lecturer of Educational Administration \\ Universitas Negeri Medan \\ Medan, Indonesia
}

\author{
Sahat Siagian \\ Lecturer of Educational Administration \\ Universitas Negeri Medan \\ Medan, Indonesia
}

\begin{abstract}
The aim of this study is to increase English terachers ability in apllying STAD type cooperative learning model through clinical supervision at SMP Negeri Kecamatan Sunggal. This research method is school Action Research. Subjects of research are the english teachers of SMP Negeri Kecamatan Sunggal. This object of reserach is applying clinical supervision for increasing english teachers ability in applying STAD type cooperative learning model. the instrument used in this research are lesson plan and observation sheet of the english teacher ability in applying cooperative learning STAD type. The result of this Action research are cycle one in planning lesson getting grade average is $\mathbf{7 1 , 2 5 \%}$ in enough category and applying cooperative learning STAD type getting grade average is $70,45 \%$ in enough category. cycle two in planning lesson getting grade average is $84,7 \%$ in good category and applying coopertive learning STAD type getting grade average is 81,81 in good category. The result of research finding, the researcher found that clinical supervision can increase the english teacher abilty in applying cooperative learning STAD type at SMP Negeri Kecamatan Sunggal. To the principal and supervisor is expected to apply and develop this clinical supervision to be a better, with expectation the teachers quality can be better that finally can get positive influence to the students.
\end{abstract}

Keywords: English teachers ability; Clinical supervision

\section{INTRODUCTION}

One of the teachers skill that they must have when they implement the learning is ability of applying learning model. Ability of a teacher in planning or selecting the right learning model when the teacher apply learning model to their students, have a role in increasing the result of learning, especially the result of learning purpose in detail. Learning model is conceptual framework that describe systematical procedure in organizing learning experience to reach the certain learning goals, and serves as a guide for learning designers and teachers in planning teaching and learning activities.Learning models cover strategies, approaches, methods, techniques and learning tactics.

Trianto (2011: 25) suggests there are six teaching models that are often and practically used by teachers in teaching, namely: (1) presentation; (2) direct instruction; (3) concept teaching; (4) cooperative learning; (5) problem-based teaching; and (6) class discussions. Teachers who wants to carry out learning to students, in choosing a model to be applied, should consider some things, such as subject matter, the level of cognitive development of students and facilities available, so that the objectives of learning that have been set can be achieved.

Based on the six models mentioned above, cooperative learning model (cooperative learning) is a model that has been applied has benefits for the success of learning.

Isjoni (2009: 20) said that cooperative learning is a small group learning activities so that students can work with other students to achieve learning objectives. In line with Artz and Newman in Trianto (2011: 56) states that in cooperative learning students learn together as a team in completing group tasks to achieve common goals. So every member of the group has the same responsibility for group success.

Rusman (2012: 206) 
Rusman (2012: 206) suggests that cooperative learning will be effectively used if: (1) teachers emphasize the importance of joint efforts in addition to individual efforts; (2) the teacher requires the equitable acquisition of results in learning; (3) teachers want to instill peer tutor or learn through their own friends; (4) teachers require equal participation of students; (5) the teacher wants the student's ability to solve various problems.

In principle there are four important elements in cooperative learning are: (1) the presence of participants who need each other and fill each other in the group; (2) the existence of rules in groups; (3) the learning effort of each group member with their respective duties and responsibilities, and (4) the objectives to be achieved through group process. The characteristics of learning with cooperative learning model are: (1) students work in groups cooperatively to complete learning materials; (2) groups formed from students with high, medium and low ability; (3) group members should be of different races, cultures, tribes, sexes; and (4) rewards are more group-oriented than individuals. Thus, the coopertive learning model requires inter-student cooperation and interdependence in the structure of task achievement, goals and rewards.

Cooperative learning according to Rusman (2012: 213) consists of six types namely type, STAD, TGT, Jigsaw, Make a Match, Group Investigasion, and structural model. As previously described, one of the cooperative learning models is the STAD type. STAD is cooperative learning type model that designed to motivate learners to help each other among learners one another in mastering the skills or knowledges presented by the teacher, Student Teams Achievement Division (STAD) also requires the learners to be active and can understand the subject matter.

Slavin (1995: 4) STAD learning refers to a variety of teaching methods in which learners work in a small groups to help each other in learning the subject matter. Cooperative learning emphasizes cooperation among learners in groups to achieve learning objectives. STAD brings an innovative concept and emphasizes student activeness which is expected to be able to improve teacher ability in applying STAD and can have positive impact to the students.

Based on the result of the preliminary observation at SMP Negeri Kecamatan Sunggal that during learning process of English still happened teacher-centered learning, the impact of this learning of student become less concentration, student activity still limited to listening, recording and doing practice questions. Student activity is still not evenly distributed, some of the students are active during the lesson. Interaction of learners has not been well coordinated in the classroom. Generally learners are less brave to ask questions. Learners rarely get a chance to find answers to the questions posed and prove his invention. Teachers mostly answer directly. Therefore, students are less able to think critically and express their opinions. Teachers should guide students to find answers through various activities directly.

Based on interviews with four grade VIII English teachers at SMP Negeri Sunggal, in the first question from four teachers, two teachers successfully answered the question while two other teachers were unable to answer. Furthermore, the second question is only one teacher who successfully answered while 3 more teachers can not answer. The third question is only one teacher who can answer while three teachers can not answer. The fourth question is only one teacher can answer while the other 3 teachers can not answer the question.

The result of preliminary study on the planning of STAD by English teacher, the result is teacher training 1 (G1) get score 62,50 in less category, teacher training $2(\mathrm{G} 2)$ get score 60,00 in less category, trainer teacher 3 (G3) scored 65.00 in the less category, and teacher training 4 (G4) scored 62.50 in the less category. The average gained by the four trainers in planning STAD is 60.62 in the less category. Furthermore, in the application of cooperative learning model type STAD is teacher training 1 (G1) get score 63,63 in less category, teacher trainer $2(\mathrm{G} 2)$ get score 61,36 in less category, teacher trainer 3 (G3) get score 65,90 in the category of less, and teacher trainer 4 (G4) get score 63,63. The average that obtained by latig teacher in applying STAD type cooperative learning model is 63,63 in less category.

Another problem is the frequency of visits of supervisors of English to the SMP Negeri kecamatan Sunggal 1 District is still rarely done. School supervisors just and visit the principal. school supervisors rarely make observations to the classroom. The supervisory methods of school supervisors are limited to general supervision and convey information through teacher meetings.

Furthermore, to improve the ability of English teachers in applying STAD type cooperative learning model is one of the techniques through clinical supervision. Sudjana (2012: 116) suggests clinical supervision as a professional assistance given to teachers who have problems in implementing the learning so that the teacher can overcome the problems they experienced related to the learning process. Meanwhile, Cogan in Sagala (2012: 246) suggests the activity of teacher performance improvement in managing the teaching and learning process. Sagala (2010: 196) argues that the application of this clinical supervision can ensure the quality of learning services in a sustainable and consistent and aims to improve the weakness or weakness of teachers in the applying learning.

Clinical supervision procedures take place in a process; shaped cycle consisting of three stages: the preliminary meeting stage, the observation stage and the reverse meeting stage. Two of the three stages require a meeting between the teacher and the supervisor, the preliminary and reverse meeting. (1) Preliminary meeting stage; In this stage the supervisor and teacher together discuss the skills plan to be observed and recorded. This stage provides an opportunity for teachers and supervisors to identify the teacher's primary concern and then translate it into a form of observable behavior. An effective and open manner is needed at this stage in order to establish good relationships between supervisors and teachers as partners in a harmonious working environment. Technically, five key steps are needed for proper preliminary meeting, namely; (1) create an intimate atmosphere between the supervisor and the teacher before the next steps are 
discussed; (2) reviewing lesson plans and lesson objectives; (3) reviewing skill components to be trained and observed; (4) choosing or developing an observational instrument that will be used to record the teacher's behavior of primary concern; (5) the selected or developed observation instruments are discussed jointly between the teacher and the supervisor. (2) Stage of teaching observation; At this stage the teacher trains the behavior of teaching based on the skill components agreed upon in the preliminary meeting. On the other hand, the supervisor observes and records or records objectively, completely, and candidly from the teacher's behavior while teaching, based on the skills component requested by the teacher to be recorded. Supervisors may also conduct observations and records student behavior in the classroom as well as teacher and student interaction. (3) Stage of reversal meeting; The feedback stage is the evaluation stage of the teacher's behavior to be analyzed and interpreted from the supervisor to the teacher. Activities in which supervisors try to analyze the data recording the behavior of teachers in teaching. Mukhtar (2013) points out the main steps in this phase are: (1) asking the general teacher's feelings or the general impression of the teacher as he teaches as well as the strengthening member in reviewing the learning objectives; (2) reviewing the target skills and teacher's primary concerns; (3) asking the teacher's feelings about the course of instruction based on the target and the main concern; (4) showing the recording data and provides an opportunity for teachers to interpret the data; (5) interpreting the data together record data; (6) asking the teacher's feelings after seeing the data record; (7) summarizing the results by looking at what the teacher wants or targets and what has actually happened or been achieved; and (8) determining jointly and encourage teachers to plan things that need to be trained or noticed at the next opportunity.

Based on the formulated problems in this research is whether through the clinical supervision can improve the ability of English teachers SMP NegeriSunggal District in applying STAD type of cooperative learning model and the purpose of this study is to determine the improvement of English teachers' ability in applying STAD through clinical supervision in SMP Negeri Kecamatan Sunggal.

\section{RESEARCH METHODS}

This research was conducted at SMP Negeri Kecamatan Sunggal, Deli Serdang Regency, North Sumatera Province. This research took place from May to July even semester of academic year 2016/2017.

This form of research is School Action Reseach (Research Action School). This action research uses a research model from Kemmis\& Mc Taggart. This research consists of two cycles which each cycle consists of planning (Planning), acting (acting), observation (observing), and reflection (reflexing).

The subject of this school action research is English teacher at SMP NegeriSunggalSubdistrict. Subject is determined by purposive sampling. The data from this action research are based on the lesson plan of learning execution (RPP), the instrument of observation sheet of STAD type cooperative learning model, and the instrument of clinical supervision sheet. Data collection techniques in this study are observation and interview.

At the planning stage of cycle I, (1) the supervisor develops the plan of implementing the school action and prepares the license for the implementation of the school action; (2) the supervisor coordinates with the school which teacher is used as the research subject and the school supervisor; (3) superviosor preparing the format of appraisal in the form of assessment and observation instruments; (4) the supervisor shall prepare a schedule of class visit activities for each teacher of chemistry; (5) supervisor prepares equipment such as books, pens, handycams and cameras for documentation. At the implementation stage, (1) there is a dialogue between teachers who are supervised clinically and supervisor with an atmosphere of openness, intimacy, mutual trust, mutual understanding and mutual respect; (2) the teacher narrates the difficulties in applying the jigsaw type cooperative learning model to the supervisor; (3) teachers and supervisors discuss the types of actions teachers will use to solve their problems; (4) teachers and supervisors set success criteria for action; (5) teachers and school supervisors prepare instruments to measure the implementation of jigsaw type cooperative learning model; (6) supervisors also prepare handycams to record how and the behavior of teachers teach in the classroom; (7) the teacher with the supervisor jointly revises the teacher's learning document (RPP), from the results of the revision the supervisor explains the things that need to be improved; and (8) supervisors and teachers set a schedule for the implementation of teacher teaching activities and sign contracts. At the observation stage, (1) the supervisor sits behind and observes the behavior of the teaching teacher, noting theadvantages and disadvantages of teachers when teaching carefully and objectively; (2) supervisors record behavior and how teachers teach by using handycam. At the stage of reflection, (1) the supervisor asks the teacher's feelings with a relax, intimate, sincere and objective atmosphere; (2) the supervisor provides teacher reinforcement; (3) the supervisor evaluates the learning objectives; (4) the supervisor recalls contracts agreed upon in the lesson; (5) teacher teaching recordings played back and viewed together by supervisors with teachers; (6) supervisors indicate which observation records are the lack of teachers implementing learning and excess teachers implementing learning; (7) supervisor also shows teacher observation record in applying STAD type cooperative learning model; (8) the supervisor discusses it with the teacher to find appropriate action so that the teacher can correct the deficiencies in the learning process; (9) the supervisor provides motivation and enthusiasm for the teacher to teach better and declares that the teacher will be able to correct the deficiency; and (10) the supervisor re-agrees with the teacher to conduct the classroom learning process with the improvements that have been discussed and the supervisor will observe again at the time the teacher teaches.

In the planning phase of cycle II, (1) the supervisor meets with the teacher to discuss the deficiencies in cycle I; and (2) 
discussing the implementation of the action in cycle II and scheduling time of the activity. In the implementation stage of the action, (1) there is a dialogue between the teacher who is supervised clinically and the supervisor with an atmosphere of openness, familiarity, mutual trust, mutual understanding and mutual respect; (2) the teacher narrates the difficulties in applying the jigsaw type cooperative learning model to the supervisor; (3) teachers and supervisors discuss the types of actions teachers will use to solve their problems; (4) teachers and supervisors set success criteria for action; (5) teachers and school supervisors prepare instruments to measure the application of STAD type cooperative learning model; (6) supervisors also prepare handycams to record how and the behavior of teachers teach in the classroom; (7) the teacher with the supervisor jointly revises the teacher's learning document (RPP), from the results of the revision the supervisor explains the things that need to be improved; and (8) supervisors and teachers set a schedule for the implementation of teacher teaching activities and sign contracts. At the observation stage, (1) the supervisor sits behind and observes the behavior of the teaching teacher, noting the advantages and disadvantages of teachers when teaching carefully and objectively; (2) supervisors record behavior and how teachers teach by using handycam. At the stage of reflection, (1) the supervisor asks the teacher's feelings with a relaxed, intimate, sincere and objective atmosphere; (2) the supervisor provides teacher reinforcement; (3) the supervisor evaluates the learning objectives; (4) the supervisor recalls contracts agreed upon in the lesson; (5) teacher teaching record played back and viewed together by (6) bsupervisor with teacher; supervisors show observation records of what is the lack of teachers implementing learning and excess teachers implementing learning; (7) supervisor also shows teacher observation record in applying STAD type cooperative learning model; (8) supervisors motivate teachers to keep improving their abilities.

\section{RESULT AND DISCUSSION}

\section{Cycle 1}

The result of the evaluation of the ability of English teachers in the learning process is the result of RPP study and the result of the ability of English teachers to apply STAD type cooperative learning model in cycle I can be seen in Table 1 below:

\begin{tabular}{|c|c|c|c|c|}
\hline \multirow{2}{*}{ No } & $\begin{array}{c}\text { Teacher } \\
\text { Code }\end{array}$ & $\begin{array}{c}\text { Percentage \% } \\
\text { ofEnglish } \\
\text { Teachers' } \\
\text { Lesson } \\
\text { Plan }\end{array}$ & $\begin{array}{c}\text { Ability of } \\
\text { English } \\
\text { Teacher } \\
\text { cooperative }\end{array}$ & \multirow{2}{*}{ Description } \\
\hline 1 & G1 & 70,00 & 68,18 & Enough \\
\hline 2 & G2 & 65,00 & 65,90 & Enough \\
\hline
\end{tabular}

\begin{tabular}{|c|c|c|c|c|}
\hline 3 & G3 & 75,00 & 72,72 & Enough \\
\hline 4 & G4 & 75,00 & 75,00 & Enough \\
\hline \multicolumn{2}{|c|}{ Average } & 71,25 & 70,45 & Enough \\
\hline
\end{tabular}

Based on table 1 above, in the first cycle the ability of English teachers in planning STAD type cooperative learning or RPP study, the average is 71,25 ie in the category enough. Furthermore, the ability of English teachers in applying STAD type cooperative learning model is 70,45 , that is in enough category. Based on the findings of the researchers in the first cycle scores obtained have not achieved the success indicator in other words the ability of English teachers in applying STAD type cooperative learning model has not reached the indicator of success, so it needs to be continued into the second cycle.

\section{Cycle 2}

The result of the evaluation of the ability of English teachers in the learning process is the result of RPP study and the result of the ability of English teachers to apply STAD type cooperative learning model in cycle II can be seen in Table 2 below:

\begin{tabular}{|c|c|c|c|l|}
\hline \multirow{2}{*}{ No } & \multirow{2}{*}{$\begin{array}{c}\text { Teacher } \\
\text { Code }\end{array}$} & $\begin{array}{c}|c| \\
\text { Review } \\
\text { ofEnglish } \\
\text { Teachers' } \\
\text { Lesson } \\
\text { Plan }\end{array}$ & $\begin{array}{c}\text { Percentage \% } \\
\text { Ability of } \\
\text { English } \\
\text { Teacher } \\
\text { cooperative }\end{array}$ & \multirow{2}{*}{ Description } \\
\hline 1 & G1 & $82,50 \%$ & $81,81 \%$ & Excellent \\
\hline 2 & G2 & $77,27 \%$ & $77,27 \%$ & Excellent \\
\hline 3 & G3 & $87,50 \%$ & $84,09 \%$ & Excellent \\
\hline 4 & G4 & $90,00 \%$ & $88,63 \%$ & Excellent \\
\hline \multicolumn{2}{|c|}{ Average } & $84,37 \%$ & $81,81 \%$ & Excellent \\
\hline
\end{tabular}

Based on table 2 above, in the second cycle of the ability of English teachers in planning STAD type cooperative learning or RPP study, the average is 84,37 in very good category. Furthermore, the ability of English teachers in applying cooperative learning model type STAD average is 81,81 that is in very good category. Based on the findings of researchers in the second cycle scores obtained have achieved the success indicator in other words the ability of English teachers in applying STAD type cooperative learning model has reached the indicator of success. 
Based on the results of the assessment conducted by the supervisor as a researcher from the pre cycle, then the first cycle and continued with the second cycle of the ability of four chemistry teachers in applying STAD type cooperative learning model in the learning process, the value of the English teacher's ability in the learning process can be described as Table 3 below:

\begin{tabular}{|c|c|c|c|c|c|c|c|}
\hline \multirow{4}{*}{$\begin{array}{l}\mathbf{N} \\
\mathbf{o}\end{array}$} & \multirow{4}{*}{$\begin{array}{l}\text { Teache } \\
\text { r Code }\end{array}$} & \multicolumn{6}{|c|}{ Score of Abilty English Teacher } \\
\hline & & \multicolumn{3}{|c|}{ Lesson Plan Review } & \multicolumn{3}{|c|}{$\begin{array}{c}\text { Applying } \\
\text { Cooperative } \\
\text { Learning Model } \\
\text { STAD Type }\end{array}$} \\
\hline & & \multirow{2}{*}{$\begin{array}{c}\text { Pra } \\
\text { Cycl } \\
\text { e }\end{array}$} & \multicolumn{2}{|c|}{ Cycle } & \multirow{2}{*}{$\begin{array}{c}\text { Pra } \\
\text { Cycl } \\
\text { e }\end{array}$} & \multicolumn{2}{|c|}{ Cycle } \\
\hline & & & I & II & & I & II \\
\hline 1 & G1 & 52,50 & $\begin{array}{c}70,0 \\
0\end{array}$ & $\begin{array}{c}82,5 \\
0\end{array}$ & 43,18 & $\begin{array}{c}68,1 \\
8\end{array}$ & $\begin{array}{c}81,8 \\
1\end{array}$ \\
\hline 2 & G2 & 47,50 & $\begin{array}{c}65,0 \\
0\end{array}$ & $\begin{array}{c}77,2 \\
7\end{array}$ & 40,90 & $\begin{array}{c}65,9 \\
0\end{array}$ & $\begin{array}{c}77,2 \\
7\end{array}$ \\
\hline 3 & G3 & 55,00 & $\begin{array}{c}75,0 \\
0\end{array}$ & $\begin{array}{c}87,5 \\
0\end{array}$ & 47,72 & $\begin{array}{c}75,0 \\
0\end{array}$ & $\begin{array}{c}84,0 \\
9\end{array}$ \\
\hline 4 & G4 & 57,50 & $\begin{array}{c}75,0 \\
0\end{array}$ & $\begin{array}{c}90,0 \\
0\end{array}$ & 50,00 & $\begin{array}{c}77,2 \\
7\end{array}$ & $\begin{array}{c}88,6 \\
3\end{array}$ \\
\hline & $\begin{array}{l}\text { erage of } \\
\text { Inglish } \\
\text { eacher } \\
\text { Score }\end{array}$ & 53,12 & $\begin{array}{c}71,2 \\
5\end{array}$ & $\begin{array}{c}84,3 \\
7\end{array}$ & 46,59 & $\begin{array}{c}70,4 \\
5\end{array}$ & $\begin{array}{c}81,8 \\
1\end{array}$ \\
\hline
\end{tabular}

Based on table 3 above, that the average value of teachers in planning the pre cycles of learning is 53,12 ie in the category of less, in cycle 1 the average score is 71,25 in the category enough, and in cycle 2 the average score is 84,37 in very good category. Furthermore, the ability of teachers in applying STAD type cooperative learning model on average cycle pre cycle is 46,59 in less category, in cycle 1 the average is 70,45 in enough category, and in cycle 2 average is 81,81 in category is very good.

\section{CONCLUSION}

Based on the results of research and discussion that have been stated before, it can be concluded that there is an increase in the ability of English teachers in applying STAD type cooperative learning model through clinical supervision at SMP NegeriKecamatanSunggal.

\section{SUGGESTION}

Based on the discussion and conclusions that have been mentioned previously, it can be identified suggestions as follows:

1. To the teacher to continue to improve their skills in science and apply STAD type cooperative learning model as an alternative in the learning process because it can improve student learning outcomes and remain open and willing to accept any updates and developments related to learning models.

2. To the principal to encourage teachers to apply STAD type cooperative learning model as an alternative in the learning process.

3. To the school supervisor in performing his duties, clinical supervision as an alternative in guiding and nurturing teachers.

4. To the Head of Education Office of Deli Serdang should provide training to supervisors to broaden their horizons about the application of clinical supervision and conduct strict and continuous supervision to school supervisors and teachers so that in performing their duties can make changes in education improvement with reference to the applicable regulations.

5. To other researchers, the results of this study is expected to be one of the references to conduct more in-depth research, especially those related to the model.

\section{REFERENCES}

[1]. Isjoni, (2009), Cooperative Learning. Bandung: Alfabeta.

[2]. Rusman,(2012),Model-model pembelajaran.Bandung: Rajawali Perss.

[3]. Sagala, S. (2009), Administrasi Pendidikan Kontemporer. Bandung: Alfabeta

[4]. Sahertian P.A. (2011),Konsep Dasar \& Teknik Supervisi Pendidikan Dalam Rangka Pengembangan Sumber Daya Manusia,. Jakarta: Rineka Cipta

[5]. Slavin, Robert. (2005), Cooperative Learning. Jakarta :Nusamedia

[6]. Trianto. (2011), Mendesain Model Pembelajaran Inovatif - Progresif. Jakarta: Kencana Prenada Media Group 